\title{
FEMICIDE OF GIRLS IN CONTEMPORARY INDIA
}

\section{Shalva Weil* and Nishi Mitra vom Berg}

\begin{abstract}
While the study of femicide has progressed recently, research into the femicide of girls is still new. The femicide of girls is the murder of girls because they are girls, and because they would have grown up to be women. This article examines different forms of girl femicide in India, a country traditionally associated with sati and infanticide. Several types of femicide in India have been identified, ranging from foeticide to intimate partner femicide, and including dowry marriage femicides, «honor»-related killings and other forms of femicide. These killings are perpetrated against a weakened minority - women and an even more weakened minority - girls. Often they are aimed at the weakest elements in society: girls hailing from Dalit, other oppressed communities.
\end{abstract}

Keywords: girl femicide, India, sati, foeticide, dowry marriages.

\section{Resumo}

Femicídio de meninas na Índia contemporânea

Enquanto o estudo do femicídio progrediu muito ultimamente, a investigação sobre o femicídio de meninas ainda é recente. O femicídio de meninas é um assassinato de meninas pelo único facto de serem meninas, e por elas um dia se tornarem mulheres. Neste artigo, analisam-se diferentes formas de femicídio de meninas na Índia, um país tradicionalmente associado ao sati e ao infanticídio. Foram identificados diversos tipos de femicídios na Índia, desde o feticídio até ao femicídio nos casais, incluindo assassinatos em casamentos envolvendo o dote ou por razões de «honra», e outras formas de femicídio. Estes assassinatos são perpetrados contra uma minoria fragilizada - mulheres - e contra uma minoria ainda mais fragilizada - meninas. Frequentemente visam os elementos mais fracos da sociedade: meninas da casta Dalit ou de outras comunidades oprimidas.

Palavras-chave: femicídio de meninas, Índia, sati, feticídio, casamentos por dote.

\footnotetext{
* $\quad$ Research Institute for Innovation in Education, Hebrew University of Jerusalem, Israel. E-mail: shalva.weil@mail.huji.ac.il Postal Address: RIFIE, Hebrew University, Mt. Scopus, Jerusalem 91905, Israel.

** Advanced Centre for Women's Studies, Tata Institute of Social Sciences, Deonar, Mumbai, 400088, India.

E-mail: nishimitra@tiss.edu
}

Acknowledgement: The authors would like to thank COST (European Cooperation in Science and Technology) for supporting networking and editing of this publication. 


\section{Résumé}

\section{Le fémicide des jeunes filles en Inde contemporaine}

Si l'étude du fémicide a progressé récemment, la recherche spécifique sur le fémicide des filles reste à explorer. Le fémicide des filles est le meurtre des filles parce qu'elles sont des filles et parce qu'elles seraient devenues des femmes. Cet article décrit les différentes formes de fémicide des filles en Inde, un pays traditionnellement associé au rite de la sati et à l'infanticide. Plusieurs types de fémicide y ont été identifiés, allant du foticide au fémicide entre des partenaires intimes, en incluant les féminines liés à la dot, les "crimes d'honneur" et d'autres formes de fémicide. Ces crimes de sang sont perpétrés contre une minorité affaiblie - les femmes - et une minorité encore plus fragilisée - les filles. Souvent, ils visent les franges les plus défavorisées de la société: les filles issues de la communauté Dalit ou des autres communautés opprimées.

Mots-clés: femicide des jaunes filles, Inde, sati, foeticide, mariage avec dot.

\section{Introduction}

The study of femicide has taken leaps forward in the past few years, spearheaded by ACUNS (Academic Council on the United Nations System), which has published five volumes on femicide to date. In addition, the COST (Cooperation on Science and Technology) Action IS1206 on «Femicide across Europe» ${ }^{1}$ has enabled networking between members hailing from 30 different countries, and resulted in several scientific publications on the subject, including a Special Issue in Current Sociology (Marcuello-Servós et al. 2016) and articles in different journals, e.g. European Journal of Criminology (Corradi and Stockl 2014) and Qualitative Sociology Review (Weil 2016a).

Femicide is the killing of women because they are women. The femicide of girls is usually implicit in the general definition of femicide. Indeed, the United Nations General Assembly has been consistent in including girls in the definition of gender-related killings of women (Weil 2015). However, an examination of the femicide of girls is rare. ${ }^{2}$ Femicide of girls can be defined as the murder of girls because they are girls, and because they would have grown up to be women. Their murder is directly associated to their sex. Thus, if a girl is killed in an accident or by a hit and run driver, that death would not be considered a girl femicide case. Nevertheless, if a girl is specifically targeted because she is a female, then that murder constitutes a girl femicide. One of the reasons that make it difficult to define the femicide of girls is that there are definitional problems in deciding who qualifies as a «girl». The definition of «who is a girl» varies from culture to culture, country to country, and state to state. In some places, a girl becomes a woman at first puberty; in other countries, a girl is considered a woman at the age of 18 or even later. 
Beyond definitional obstacles, it can be stated that the femicide of girls is widespread the world over, but in some cultures there are greater numbers of femicides of young girls and female children relative to other forms of homicide or femicide, while in other societies the femicide of girls is scarce. The killing of girls occurs in European Western societies as well as non-Western societies. In some places, it takes place in a hidden way. In other countries, it is perpetuated systematically. One of the latter countries is India, where the murder of girls has been documented in colonial times, but continues today in institutionalized ways, despite legal provisions against it and state policies supporting girls.

This article focuses on the issue of vulnerability of Indian girls to a culture of femicide. It also aims to explore the historical and cultural links between femicide of women and girls. Finally, it states that the legal responses are not sufficient to tackle the problem and an integrated and focused approach to the issue is needed.

\section{The History of Girl Femicides in India}

In colonial India, certain forms of girl femicide were associated with ancient Hinduism. The most infamous was sati, the Hindu practice of self-immolation after the death of a husband. Coerced sati was tantamount to femicide, according to modern definitions, but it is important to point out that in practice most satis were child widows, and de facto they were girl femicides.

While the fact that many satis were child widows, rather than adults, was rarely a central theme of colonial critiques, invoking this additional factor of age certainly added weight to paternalistic claims that potential satis were unable to speak for themselves and needed the authorities to do so on their behalf (Grey 2013, 500).

The British colonialists paid exaggerated attention to sati in order to show that the Raj was civilizing and therefore beneficial, and that Hinduism was a barbaric religion. According to Grey (2013), the fate of a Hindu woman or girl after the death of her husband relied on her having already survived infancy. Grey points out that tribal peoples, particularly in north-west India, practiced female femicide, and the dilemma for the colonial authorities was that infanticide was strictly rejected in Hindu religious belief systems, yet sati was eulogized. One problem for the British was that Hindu women were not only the potential victims of female infanticide but, in the majority of cases, also the perpetrators of the crimes. The colonialists resolved the issue by linking sati to female infanticide and arguing that they were inextricably linked to the repressed state of women in Hinduism, enforced by Hindu men (Grey 2013, 503).

Sati was officially prohibited in 1829 , but continued unabated for over a century. Today, the practice has all but died out, and the last known case 
reported was that of Roop Kanwar in 1987 (Oldenburg 1994). Kanwar was a Rajput woman who was probably forced to immolate herself on her husband's funeral pyre at Deorala village in the Sikar district of Rajasthan. At the time of her death, she was 18 years old, childless, and had been married for eight months to her husband, who had died a day earlier at age 24. From a contemporary Western point of view, this well-known case of sati involved a child marriage of a girl under the age of 18, and an apparently coerced sati or femicide of a young woman. It is significant that all eleven defendants tried and accused of glorifying sati after Kanwar's death were acquitted as late as 2004. The situation in India does not appear to have improved for some young girls and women, but the use of modern technological devices has masked traditional religious practices. Sati is outlawed, but to this day it is glorified in various parts of Rajasthan and sati temples attract congregations and festivals on special occasions.

\section{Missing Girls in India Today}

The overriding problem in India today is the relatively high rate of girl femicide through sex selective abortions. Indicative of this phenomenon is the skewed sex ratio. According to the population Census of 2011, India had 944 females per 1000 males (Ministry of Home Affairs 2011). There is still not only son preference in India, but also a widespread mentality of considering sons indispensable and daughters dispensable (Ahlawat 2013).

Nobel Laureate Amartya Sen (1990) brought focus to the issues of femicide, and even foeticide, by talking of India's «missing women» problem. Rita Banerji has been campaigning for over a decade about the 50 million missing women and girls, many of them killed before they are born in a conscious sex-selection decision taken by men and women. In Sex and Power: Defining History, Shaping Societies, she traces the relationship between sex and power, which leads, in her opinion, to what she calls «female genocide» (Banerji 2009). Even if we do not accept this rhetoric, ${ }^{3}$ attention has been brought to the fact that femicide in India has reached alarming proportions, thanks to the advocacy of Banerji and others; it is particularly noticeable in some states like Haryana, Punjab, Jammu and Kashmir, Delhi, Chandigarh and Lakshadweep. Scarcity of young marriageable girls in the worst affected regions in Punjab and Haryana has led to «male marriage squeeze» with young men finding it difficult to find brides (Ahlawat 2009). Mapping the adverse consequences of sex selection and gender imbalance, Kaur (2013) fears that the many gains made by women in India (and China) might be endangered. She considers the possibility that the threat of violence in the case of shortage of girls may lead to reinforcement of women's gendered roles in repro-

3

«Females do not constitute a genus, and a genus cannot continue without females» (Weil 2016b). 
duction, domestic and care work, with early marriage being seen as a solution to safeguarding the virginity of girls before marriage. She writes:

women would have little agency of their own and could indeed suffer a deterioration in their equity prospects [...] as female security gets compromised [...], parents may withdraw unmarried girls from school or higher education, or restrict them from taking up employment before marriage (Kaur 2013, 43).

\section{A Typology of Femicide of Girls}

Femicide of girls in India falls into several categories. Some of these categories overlap, but they are heuristically useful in order to analyze sociologically the Indian situation:

- Female Foeticide

- Female Infanticide

- Dowry murder femicides

- Femicides by intimate partners

- «Honor»-related killings

- Other «stranger» femicides

\section{Female Foeticide}

Foeticide is the killing of a foetus or forced abortion, usually of a girl. It is difficult to estimate how many female foetuses are aborted per annum, since most of the foeticides are carried out illegally and remain unreported. In India, irrespective of caste, religion or class, most families to this day still prefer the birth of a boy, even if they are of middle-class or upper middle-class origin. The practice of foeticide emerges from the hardship girls are perceived to inflict on their families due to ancient dowry practices (Kumari 2013). According to traditional Hindu caste rules, a family has to provide large sums of money and property at marriage in order to marry his daughter. The result may be sex-selection before birth, thereby enabling some families to avoid the stigma of an unmarried daughter or expenses entailed in marrying one; instead, they prefer to give birth to males so that they receive prestige and wealth at marriage (Haveripeth 2013). In villages and in times past, foeticide was carried out by traditional means, but today abortions are common and family members resort to the use of modern reproductive technologies. In an ethnographic study in Punjab and Haryana regions in India, Ahlawat (2009) found that in both rural and urban sites, in villages and towns, a small family norm is being practiced by deliberate de-selection of girls. Affluent and educated households across caste lines were found to 
use sex selective technologies, particularly from the second order birth onwards. In a chilling book entitled Disappearing Daughters, Aravamudam (2007) quotes an informant from Chandigarh who had five abortions in four years, and whose husband insisted that she go through with them all at the clinic. According to the author, in this way, femicide is perpetrated and the ultrasound machine has mutated into an instrument of murder.

\section{Female Infanticide}

According to a 2008 UNICEF report: «India alone accounts for one fifth of under-five deaths worldwide, with 2.1 million in 2006.» ${ }^{4}$ From this same report, we acknowledge that:

Female and male children face alarmingly different rates of morbidity and mortality in India. The under-five mortality rate for girls (79 per 1,000) in 2005-2006 was substantially higher than for boys (70 per 1,000 live births). At birth, girl babies have an only marginally higher mortality rate (58 per 1,000 live births) than boy babies (56 per 1,000 live births.) However, from age 1-4 years, the mortality rate for girls is 61 per cent higher than for boys, contributing to India's overall male-female population imbalance. The female-to-male sex ratio has declined substantially during the past decade, resulting in a substantial female deficit in the population (UNICEF 2008, 25).

Further, according to India's own Ministry of Statistics and Programme Implementation, for every 56 boys who die in the $0-5$ category, there are 100 girls that die (Ministry of Statistics and Programme Implementation 2012).

If female foeticide has failed, or was not attempted, and if a girl is born, she may still be unwanted among some Indians. In urban slums or poor villages, if there is not enough food to go round, baby girls are starved or not offered food and therefore die. Baby boys are given preference. While malnutrition or starvation is a primary cause of femicide, lack of access to health facilities is another. If a baby girl gets ill, poor families may not pay out for medicines that they may offer baby boys. The result is skewed statistics for gender on infant mortality in India. Among some castes or families, the prevention of use of medicine may be subconscious; among others, it may be deliberate. In Disappearing Daughters, Aravamudam (2007) describes modern techniques of femicide which receive legitimation. For example, a family may wrap a just-born baby in a cold wet towel, thereby inducing pneumonia. The baby is taken to a doctor, who prescribes medicine, which is abandoned. When the baby dies, a medical certificate,

4 Available at https://www.unicef.org/eapro/soap_latest_-_4_Aug_08.pdf, page 4 [accessed 19.11.2016]. 
when available, legitimizes the death. According to a 2005 study reported in The Lancet, girls in central India had a five times higher mortality rate (per 1000 live births) from pneumonia than did boys in south India and four times higher mortality rate from diarrhea diseases than did boys in west India (Jha et al. 2011). Better opportunities for girl's education, expanding labor market opportunities for women, and increasing urbanization still do not address the conception of girls as a burden or guarantee daughters equal status to sons. Neither nutrition and health, nor education and leisure are considered the rights of girls, even among affluent families in India (Sekher and Hatti 2010).

\section{Intimate partner and dowry marriage femicides}

In the West, intimate partner femicides are the most common form of female homicides. According to Stöckl et al. (2013), intimate partners commit at least 41 percent of all female homicides and 6 percent of male homicides. In India, statistics are unavailable about intimate partner femicides, except some that are emerging lately in relation to dowry murders and domestic cruelty. In a 2014 compendium of crime in India, femicide was not mentioned once. However, in 2014 alone, 8455 dowry deaths were reported, of which one third of its authors were convicted (Ministry of Home Affairs 2014). It should be pointed out that dowry murders are concentrated in particular states in India, with the highest incidences in Uttar Pradesh and Bihar.

Dowry murders are associated with the large amounts of money families have to pay at marriage in order to marry off their daughters. Dowry marriage killings often involve mothers-in-law and sisters-in-law, which shows the vulnerability of young brides on grounds of age and affinal relations due to their low status in the marital home. Increasing demand for dowry and commercialization of marriage in recent times has converted an ancient practice of a form of inheritance for girls into a form of extortion (Bloch and Rao 2002).

Different forms of physical abuse are related to dowry marriages (Singh 2013). These include kerosene stove deaths, bride drowning, poisoning and suicides by self-immolation, some of which are difficult to prove that they were in fact murders. A study reported in The Lancet made the revelation that in one year at least 106,000 women were killed by fires in their homes in India. These statistics point to one woman being burned to death every five minutes (Ellsberg et al. 2008).

\section{«Honor»-related killings}

Both Hindus and Muslims, the predominant religions in India, have elaborate conceptions of honor and dishonor related to women and their conduct. The framework of patriarchal family structures, communities and societies, maintains the main justification for the perpetration of violence as the compulsion to pro- 
tect the social honor of the community, and the family as a value (Gill 2015). Tradition is upheld as the most important element of community life, which is threatened by individual violation of it through marriages or transgressions outside its norms. On that continuum, «honor» killings constitute the most extreme of a wide range of violent and abusive acts. Utilizing a theoretical framework from Bourdieu, Gryzb shows that masculine domination is a fine example of symbolic violence (Grzyb 2016).

Although so-called «honor» killings are associated with Islam and the Middle East, the «Honor Diaries» website showed that, as of 26 October 2016, of 5000 known «honor» killings carried out in the world per annum, 1000 are carried out each year in India. ${ }^{5}$ According to the 2011 census (Ministry of Home Affairs 2011), India's Muslim population is 172 million - the world's third largest and the world's largest Muslim-minority population. However, not all these «honor» killings are in fact perpetrated within the Muslim population. Moreover, the numbers are clearly far greater. Often the murders are couched as suicides or accidents, and are silenced.

The concept of izzat (honor), prevalent in North India and Pakistan, is a valued ideal that signifies status in the social hierarchy through patriarchal control of the community and family of the behavior and conduct of its kinship, particularly women (Chakravarti 2006). Within the Hindu religion, claims of «honor» can be heard when a high-caste boy or girl marries a Dalit («Untouchable») or lower caste person of the opposite sex. Both Hindus and Muslims place high value on women's modesty and appropriate conduct so that the honor of a family is deemed to increase or decrease depending on women's behavior. Marriage outside of caste and religion is seen to be dishonorable and polluting, and is severely punished by family members and the community. Young girls who marry outside their caste and religion are targeted for punishment, often with death sentence, in order to uphold the idealized norms of the community. Despite the existence of a secular legal system in India, there is an increase in recent years in the unlawful interference of caste based assemblies or kangaroo courts locally (khap panchayat), which harass and victimize young girls and their families through arbitrary death sentences in case they marry outside their caste. A number of cases go unreported despite illegality of these acts for fear of reprisals, as powerful village seniors are involved and there is a silencing of the community through the threat of violence (Bharadwaj 2012). Some girls in runaway marriages, or marriages of love, face death through the flagrant violation of the rule of law, where panchayat members take law into their own hands. ${ }^{6}$

Available at http:/ / www.honordiaries.com/wp-content/uploads/2013/06/HD-FactSheet-HonorViolenceEast.pdf.

6

See: «Five Decisions by the Khap Panchayat that took us back to the Dark Ages.» Posted on September 18, 2015. http:/ / www.womensweb.in/2015/09/5-decisions-by-khap-panchayats-tookus-back-dark-ages. Accessed 5.8.2016. 


\section{«Stranger» Femicides}

Non-intimate girl femicides include kidnapping for prostitution and trafficking, and rape of young girls followed by murder, due to non-compliance. Dalit girls are routinely violated and at times killed brutally to shame and humiliate the community on caste grounds. The police response to these murders is selective with little outrage and high caste violators are shielded. ${ }^{7}$

Other forms of «stranger» femicides can be seen in those communities which mistreat and accuse lower caste and poor women of being witches, which sometimes ends up in death. However, witches are usually older women and rarely girls.

An exceptional case of «stranger» femicide is that of a young girl, who was murdered for religious sacrifice. In 2012, it was reported that a five-year-old Dalit girl called Rajlakshmi was sacrificed on a full moon day based on the superstitious belief that if her blood were sprinkled at the construction site where her parents were working it would give the structure life and enduring strength. ${ }^{8}$ When the body was found, it was devoid of blood, and the flesh near the child's face had been cut using a sharp weapon. The incident sent shock waves throughout India.

\section{Conclusions}

This article examined the femicide of girls in India within a historical and culture-specific context. It provided a typology of different kinds of girl femicide, pointing out their unique aspects within India. Femicide of girls is a challenging and multi-faceted issue. The article discussed girl femicide as one form of global femicide. Some of the phenomena described are general and global, and are widespread in other countries. Other practices, such as dowry marriage femicide, and different forms of «honor»-related killings, or «caste» girl murders, are unique to India.

The femicide of girls in India is rooted in ancient practices, and some manifestations were noted by colonialists. In contemporary India, femicide of girls consists of several types of different crimes, ranging from foeticide to infanticide, to intimate partner femicide. The murder of girls in India because they are girls and would grow up to be women are perpetrated against a weakened minority women - and an even more weakened minority - girls. Often they are aimed at

See: «Casting Rape: 101 Cases of Sexual Violence Against Dalit Women After Damini that Failed to Generate Mainstream Outrage.» Posted on September 8, 2013. http:/ / www.indiaresists.com/afterdamini-101-brutal-atrocities-heinous-crime-against-dalit-women-india. Accessed 5.8.2016.

8 See: Karthikeyan D. «Hapless Dalit girl child a victim of Superstition.» Posted on April 29, 2012 http:/ / www.thehindu.com/news/ cities/Madurai/hapless-dalit-girl-child-a-victim-of-superstition/article3364983.ece [accessed 5.8.2016]. 
the weakest elements in society: girls hailing from Dalit or oppressed and discriminated members of other communities. It appears that the femicide of girls in India is higher than in some Western countries due to the early age at marriage in India, where a «girl» is considered a «woman», and due to arranged marriage practices, and specifically dowry marriage. While sex-selection prior to birth is known in other countries, it appears that the culture of femicide encourages abortions of females among many sectors of society in India.

These crimes have to be eradicated, and the killing of girls because they are not boys has to terminate. The problem is not new to India, as we have shown. In contemporary India, however, new technological devices perpetuate the femicide of girls by innovative means. The sex ratio at birth in India shows that the problem of femicide begins even before girls are born and is influenced by antenatal sex selection. Ironically, in the modern era, sex ratios have deteriorated in favor of males. Though the Indian Government passed the Pre-natal Diagnostic Techniques Regulation and Prevention of Misuse (PNDT) Act in 1994 that made sex selective abortions illegal, this law has had little impact on the problem. Studies show significant drop in the sex ratios after the 1980s, when ultra-sound machines for the antenatal sex determination became available (Miller 2001; Patel 2007).

Legislation is not always the answer when the causes of femicide and, in particular, girl femicide in India are deeply ingrained in culture. A 2005 law, The Protection of Women from Domestic Violence Act, was aimed at protecting women and girls from different forms of intimate violence, but has been difficult to enforce. Many women are forced to withdraw their complaints of abuse and cruelty by their husbands and relatives due to their dependence on them and the non-implementation of existing laws. Some are compelled to commit suicide due to inability to compromise and bear with the excessive violence (Solotaroff and Pande, 2014). The big challenge is how to implement various laws aimed at protecting girls (and women) throughout the life cycle, and further, how to tackle the problem utilizing an integrated and focused approach to the issue.

Community initiatives and grass root interventions are useful to help change mind-sets and prevent femicide. But these are insufficient. A joint and systematic evidence-based campaign against femicides of all kinds in India needs to be launched so that different stakeholders recognize the magnitude of the problem. The problem is even more repulsive when one is talking about girls, who have not yet had a chance to grow up to be women.

\section{Bibliographical References}

Ahlawat, Neerja. 2009. «Missing Brides in Rural Haryana». Social Change 39(1): 46-63. Ahlawat, Neerja. 2013. «Dispensable Daughters and Indispensable Sons: Discrete Family Choices». Social Change 43(3): 365-376. DOI: https: / / doi.org/10.1177/0049085 713494296 
Aravamudam, Gita. 2007. Disappearing Daughters: The Tragedy of Female Foeticide. New Delhi: Penguin.

Banerji, Rita. 2009. Sex and Power: Defining History, Shaping Societies. London: Penguin.

Bharadwaj, Suraj Bhan. 2012. «Myth and Reality of the Khap Panchayats: A Historical Analysis of the Panchayat and Khap Panchayat». Studies in History 28(1): 43-67. DOI: https: / / doi.org/10.1177/0257643013477250

Bloch, Francis, and Vijayendra Rao. 2002. «Terror as a Bargaining Instrument: A Case Study of Dowry Violence in Rural India». American Economic Review 92(4): 1029 1043. DOI: https: / / doi.org/10.1257/00028280260344588

Chakravarti, Uma. 2006. Gendering Caste through a Feminist Lens. Calcutta: Stree.

Corradi, Consuelo, and Heidi Stöckl. 2014. «Intimate partner homicide in 10 European countries: Statistical data and policy development in a cross-national perspective». European Journal of Criminology 11(5): 601-618. DOI: https: / / doi.org/10.1177/14773 70814539438

Ellsberg, Mary et al. 2008. «Intimate Partner Violence and Women's Physical and Mental Health in the WHO Multi-country Study on Women's Health and Domestic Violence: An Observational Study». The Lancet 371(9619): 1165-1172. DOI: https:/ / doi. org/10.1016/S0140-6736(08)60522-X

Gill, Aisha. 2015. «Honor Based Violence and so called Honor Killings». In Femicide: Global Issue that Demands Action, Vol. IV, edited by Milica Dimitrijevic, Andrada Filip, and Michael Platzer, 71-74. Vienna: ACUNS. Available at http:/ / acuns.org/femicide-aglobal-issue-that-demands-action-volume-iv /

Grey, Daniel J. R. 2013. "Creating the 'Problem Hindu': Sati, Thuggee and Female Infanticide in India». Gender and History 25(3): 498-510. DOI: https:// doi.org/10.1111/ 1468-0424.12035

Grzyb, Magdalena A. 2016. «An Explanation of Honor-related Killings of Women in Europe through Bourdieu's Concept of Symbolic Violence and Masculine Domination». Current Sociology 64(7): 1036-1053. DOI: https: / / doi.org/10.1177/ 0011392115627479

Haveripeth, Prakash D. 2013. «Causes and Consequences of Dowry Menace in India - a Criminological Perspective». Radix International Journal of Research in Social Science, 2(2): 1-15. Available at http: / / www.rierc.org/ social/ paper173.pdf

Jha, Prabhat et al. 2011. «Trends in selective abortions of girls in India: Analysis of nationally representative birth histories from 1990 to 2005 and census data from 1991 to 2011». The Lancet 377(9781): 1921-1928. DOI: https:// doi.org/10.1016/S01406736(11)60649-1

Kaur, Ravinder. 2013. «Mapping the Adverse Consequences of Sex Selection and Gender Imbalance in India and China». Economic and Political Weekly 48(35): 37-43. Available at http: / / www.epw.in/taxonomy / term/18098

Kumari, Ranjana. 2013. «How do we fight Femicide: Best Practices and Strategies». In Femicide: A global issue that demands action, edited by Claire Laurent, Michael Platzer, and Maria Idomir, 37-41. Vienna: ACUNS. Available at http: / / acuns.org/femicidea-global-issue-that-demands-action/

Marcuello-Servós, Chaime, Consuelo Corradi, Shalva Weil and Santiago Boira. 2016. «Femicide: a Social Challenge». Current Sociology 64(7): 967-974. DOI: https:/ / doi. org / 10.1177/0011392116639358

Miller, Barbara D. 2001. «Female-Selective Abortion in Asia: Patterns, Policies and Debates». American Anthropologist 103(4): 1083-1095. DOI: https://doi.org/10.1525/ aa.2001.103.4.1083

Ministry of Home Affairs, Government of India. 2011. «Census Reference Tables». Avail- 
able at http: / / censusindia.gov.in/Tables_Published/Tables_published.html [accessed 5.8.2016].

Ministry of Home Affairs, Government of India. 2014. Crime in India 2014. New Delhi: National Crime Records Bureau, Ministry of Home Affairs. Available at http: / / ncrb.nic.in/StatPublications / CII / CII2014/Compendium\%202014.pdf [accessed on 5.8.2016].

Ministry of Statistics and Programme Implementation, Government of India. 2012. Children In India 2012: A Statistical Appraisal. Available at http://mospi.nic.in/publication/children-india-2012 [accessed 5.8.2016].

Oldenburg, Veena T. 1994. «The Roop Kanwar case: Feminist Responses». In Sati, the Blessing and the Curse: the Burning of Wives in India, edited by John S. Hawley, 101-130. New York: Oxford University Press.

Patel, Tulsi. 2007. Sex Selective Abortion in India: Gender, Society and New Reproductive Technologies. Delhi: Sage. DOI: https: / / doi.org/10.4135/9788178299587

Sekher, Tom, and Neelambar Hatti. 2010. «Disappearing Daughters and Intensification of Gender Bias: Evidence from Two Village Studies in South India». Sociological Bulletin 59(1):111-133. Available at http:/ / www.unfpa.org/sites/default/ files/resourcepdf/UNFPA_Publication-39840.pdf

Sen, Amartya. 1990. «More than 100 Million Women are Missing». New York Review of Books, December 20: 61-66. Available at http://www.nybooks.com/articles/1990/ 12/20/more-than-100-million-women-are-missing/

Singh, Mahek. 2013. «Dowry as a Factor of Violence in Marriage: A study of women seeking help in Family Counseling Centers in Chandigarh». International Journal of Advancements in Research \& Technology 2(6): 40-52. Available at http://www.ijoart. org/ResearchPaperPublishing_June2013.shtml

Solotaroff, Jennifer L., and Pande, Rohini P. 2014. Violence against Women and Girls: Lessons from South Asia. Washington, DC: South Asia Development Forum, World Bank. Available at http: / / hdl.handle.net/10986/20153 [accessed 5.8.2016].

Stöckl, Heidi et al. 2013. «The global prevalence of intimate partner homicide: a systematic review». The Lancet 382 (9895): 859-865. DOI: https: / / doi.org/10.1016/S01406736(13)61030-2

UNICEF - United Nations International Children's Emergency Fund. 2008. The State of Asia Pacific's Children 2008: Child Survival. New York: UNICEF. Available at https:/ / www.unicef.org/eapro/soap_latest_-_4_Aug_08.pdf

Weil, Shalva. 2015. «Femicide in Europe». In Femicide: a Global Issue that Demands Action, Vol. IV, edited by Milica Dimitrijevic, Andrada Filip, and Michael Platzer, 118-123. Vienna: ACUNS. Available at http:/ / acuns.org/femicide-a-global-issue-thatdemands-action-volume-iv/

Weil, Shalva. 2016a. «Failed Femicides among Migrant Survivors». Qualitative Sociology Review 12(4): 6-21. Available at http:/ / www.qualitativesociologyreview.org/ENG/ volume39.php

Weil, Shalva. 2016b. «Making Femicide Visible». Current Sociology 64(7): 1124-1137. DOI: https: / / doi.org/10.1177/0011392115623602

Shalva Weil. Senior Researcher at the Hebrew University of Jerusalem, Israel, and Research Fellow in the Department of Biblical and Ancient Studies, at UNISA. She has published 80 articles in scientific journals. Her books include: India's Jewish Heritage (Marg), Karmic Passages (OUP), and Roots and Routes (Magnes). Prof. Weil serves 
as Chair of the Cost Action IS1206 on Femicide across Europe. She has spoken on femicide in the Parliaments of Portugal (2014), Aragon (2015) and Italy (2016), and in the U.N. in Bangkok (2014) and New York (2015). She has contributed to the ACUNS 2015 volumes Femicide 3+ 4. She is co-editor of Special Issues on Femicide in Current Sociology, and Qualitative Sociology Review.

Nishi Mitra vom Berg. Associate Professor in Advanced Centre for Women's Studies, School of Development Studies, Tata Institute of Social Sciences, India. She is a social-cultural anthropologist by training and has conducted a number of pioneering researches on the issue of domestic violence and intimate and sexual violence against women and young girls in India. She is engaged in training of police, judges and other legal functionaries for sensitive handling of women victims of violence and abuse.

Article received on 7 of August 2016, accepted for publication on October 20, 2016. 